Brit. J. prev. soc. Med. (1970), 24, 58-60

\title{
ENVIRONMENTAL FACTORS IN THE AETIOLOGY OF LUNG CANCER AND BRONCHITIS
}

\author{
M. J. GARDNER, B.Sc., Dip.Math.Stat. \\ Medical Research Council's Social Medicine Unit, The London School of Hygiene and Tropical Medicine, \\ Keppel Street, London, W.C.1
}

AND

R. E. WALLER, B.sc.

Medical Research Council's Air Pollution Unit, St. Bartholomew's Hospital Medical College, London, E.C.1

THE conclusions concerning the relationship of air pollution and lung cancer mortality in a paper in the previous issue of this Journal (Ashley, 1969) are opposite to those reported in the preceding issue (Gardner, Crawford and Morris, 1969) and in other studies reported earlier by many authors. Workers in the field of epidemiology are well aware of the importance of looking at their data correctly and of the difficulties of placing aetiological interpretations on associations found between environmental factors and mortality rates. Errors that arise from not doing so are only too well demonstrated in the paper by Ashley (1969), and in an earlier paper by him (Ashley, 1967).

It is not our concern here to attempt a review of this field (the Royal College of Physicians' Report (1970) does that) but to look closely at some details of Ashley's paper. An unusual feature one notices is the use of a 'modified Standardized Mortality Ratio', calculated separately for each County Borough according to whether it formed part of a conurbation, and if not, whether its population was over 100,000 or $50,000-100,000$. This is done on the grounds that since both lung cancer and bronchitis mortality are related to town size, a modification should be made before proceeding further. The implicit assumption is that something 'urban' is operating; and one wonders whether this same undefined 'urban' factor is producing a similar relationship of town size with mortality from suicide and from syphilis and an opposite one with mortality from accidental deaths (Registrar-General, 1967). A number of environmental factors, in particular air pollution and population density, are related to town size, and part of their association with mortality willo be lost if the modified S.M.R.s are used.

Three calculations are helpful. First, the mean S.M.R.s from lung cancer in males for County? Boroughs in the three urban aggregates above are 121, 108 and 103 respectively (Registrar-General, 1967). Ashley's S.M.R.s have means of 99,114 and 114 , showing a gross distortion of the towns in the conurbations. Secondly, the correlation between population (Registrar-General, 1961) and the S.M.R. from lung cancer in males (Registrar-General, 1967) for towns outside the conurbations is +0.31 whereas with Ashley's S.M.R. it is +0.22 . This suggests that the procedure used has by no means eliminated the influence of town size, even if to do so were correct. Thirdly, the correlations between sulphur dioxide and the two S.M.R.s are +0.26 and -0.20 respectively; we have been unable to reproduce the published value of -0.23 for the latter coefficient from the data (Ashley, 1967). This reversal from a positive to a negative coefficient is due, we suggest, to the inappropriate modification. The Figure makes clear that, because of the association of town size and $\mathrm{SO}_{2}$, towns low in $\mathrm{SO}_{2}$ have had their S.M.R.s 'modified' upwards in general, and vice versa.

There is little information in the papers of Ashley $(1967,1969)$ on the way in which pollution data were selected from the tables published by the Department of Scientific and Industrial Research (1963). Inspection shows that they represent values for the 

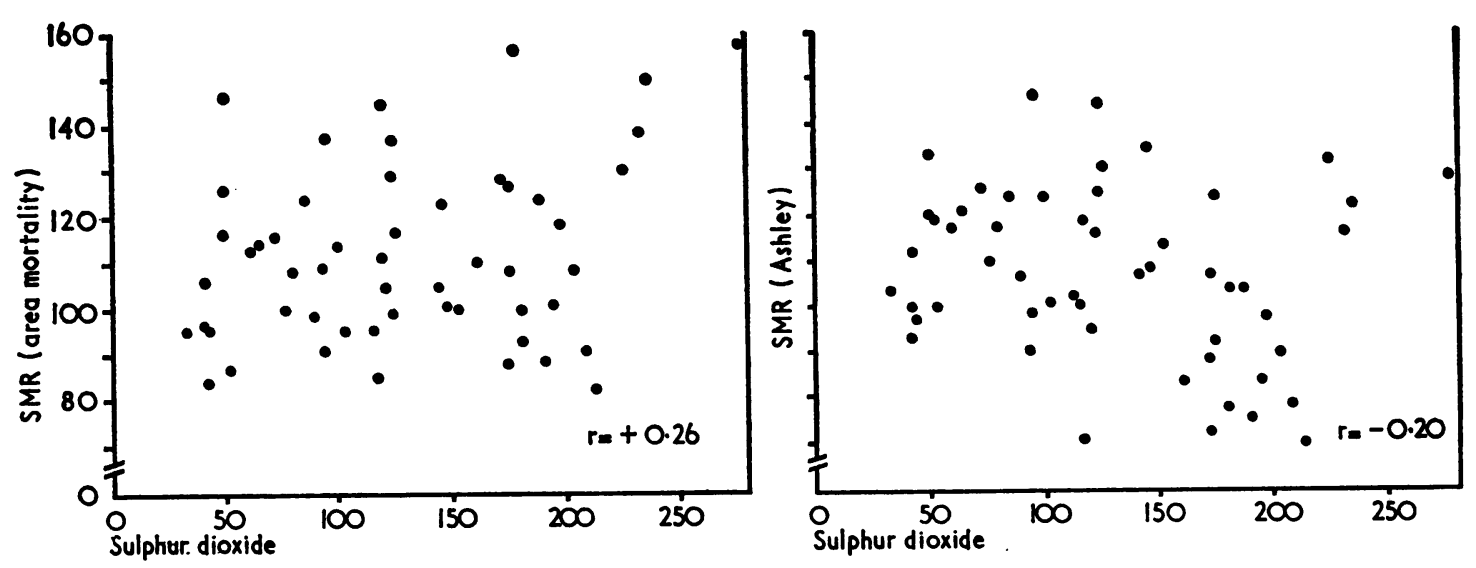

Fioure.-Mortality from lung cancer and concentration of sulphur dioxide ( $\left.\mu_{\mathrm{g} .} / \mathrm{m} .{ }^{\prime}\right)$.

month of March 1963 at category B sites, in the less densely populated residential districts of the towns. By limiting the choice to this category the contrast between towns is much reduced, and the values are

TABLE

MEAN CONCENTRATIONS OF SMOKE AND SULPHUR DIOXIDE AT 'B' AND 'A' SITES IN COUNTY BOROUGHS, MARCH 1963

(All figures in $\mu \mathrm{g} . / \mathrm{m} .{ }^{2}$ )

\begin{tabular}{|c|c|c|c|c|}
\hline \multirow{2}{*}{ County Borough } & \multicolumn{2}{|c|}{ 'B' Sites } & \multicolumn{2}{|c|}{ 'A' Sites } \\
\hline & Smoke & $\mathrm{SO}_{2}$ & Smoke & SO \\
\hline $\begin{array}{l}\text { Barnsley } \\
\text { Barrow-in-Furness } \\
\text { Bath } \\
\text { Birkenhead } \\
\text { Birmingham } \\
\text { Blackburn } \\
\text { Blackpool } \\
\text { Bolton } \\
\text { Bootle } \\
\text { Bournemouth }\end{array}$ & $\begin{array}{l}191 \\
42 \\
73 \\
117 \\
214 \\
170 \\
198 \\
172 \\
61\end{array}$ & $\begin{array}{l}124^{*} \\
\overline{44} \\
86 \\
136^{*} \\
143 \\
175^{\circ} \\
232^{*} \\
233 \\
102\end{array}$ & $\begin{array}{r}\frac{227}{52} \\
263 \\
170 \\
264 \\
\overline{311} \\
330 \\
62\end{array}$ & $\begin{array}{l}179 \\
44 \\
286 \\
195 \\
210 \\
\frac{269}{376} \\
101\end{array}$ \\
\hline
\end{tabular}

-These figures were either not included by Ashley, or differ from those quoted in his paper.

not relevant to the main population. The effect is illustrated in the Table, in which the mean concentrations at all the ' $B$ ' sites that were operational in March 1963 are shown together with the corresponding means at ' $A$ ' sites, in the more densely populated residential districts. As in Ashley's original selection, sites in smoke control areas have been excluded.

Only the first few County Boroughs, in alphabetical order, are listed here, but from these it can be seen that in the 'cleaner' towns, such as Bath and
Bournemouth, concentrations at ' $B$ ' sites alone could be regarded as typical of the towns in which they are situated; whereas in some others, such as Birkenhead, they give a gross underestimate of the pollution to which large sections of the population are subjected.

There are also dangers in using mean values over as short a period as one month, for if there are marked contrasts in weather between different parts of the country, the distribution of pollution may be distorted. It is more satisfactory to use mean values over periods of at least one year, and there must in any case be reservations about the use of contemporary pollution data in mortality studies (Waller, 1966).

Since the basic material is inappropriate, we regard the further analyses and conclusions of Ashley (1969) as invalid.

\section{REFERENCES}

AsHLeY, D. J. B. (1967). The distribution of lung cancer and bronchitis in England and Wales. Brit. J. Cancer, 21, 243.

- (1969). Environmental factors in the aetiology of lung cancer and bronchitis. Brit. J. prev. soc. Med., 23, 258.

Department of Scientific and Industrial Research (now Ministry of Technology) (1963). The Investigation of Atmospheric Pollution. Tables of observations for the year ended March 1963. Warren Spring Laboratory, Stevenage

Gardner, M. J., Crawford, M. D., and Morris, J. N. (1969). Patterns of mortality in middle and early old age in the County Boroughs of England and Wales. Brit. J. prev. soc. Med., 23, 133. 
Rzgistrar-General (1961). Census, England and Wales. Royal College of Physicians (1970). Report on Air County Reports. H.M.S.O., London.

(1967). Decennial Supplement, England and Wales, 1961. Area Mortality Tables. H.M.S.O., London.

WALLER, R. E. (1966). The interpretation and use of data on air pollution in epidemiological research. The Statistician, 16, 45.

APPENDIX TABLE

DATA USED IN FIGURE

\begin{tabular}{|c|c|c|c|}
\hline \multirow{2}{*}{ County Boroughs } & \multicolumn{2}{|c|}{ S.M.R. Lung Cancer } & \multirow{2}{*}{$\begin{array}{c}\text { Sulphur Dioxide } \\
\text { (Ashley, March 1963) }\end{array}$} \\
\hline & $\begin{array}{l}\text { Registrar- } \\
\text { General } \\
1959-63\end{array}$ & $\begin{array}{r}\text { Ashley } \\
1958-63\end{array}$ & \\
\hline $\begin{array}{l}\text { Barnsley } \\
\text { Bath } \\
\text { Birkenhead } \\
\text { Blackburn } \\
\text { Blackpool } \\
\text { Bolton } \\
\text { Bootle } \\
\text { Bournemouth } \\
\text { Bradford } \\
\text { Bristol } \\
\text { Burnley } \\
\text { Bury } \\
\text { Chester } \\
\text { Coventry } \\
\text { Croydon } \\
\text { Derby } \\
\text { Eastbourne } \\
\text { Exeter } \\
\text { Gateshead } \\
\text { Halifax } \\
\text { Huddersfield } \\
\text { Ipswich } \\
\text { Ringston upon Hull } \\
\text { Leeds } \\
\text { Leicester } \\
\text { Lincoln } \\
\text { Liverpool } \\
\text { Manchester } \\
\text { Middlesbrough } \\
\text { Newcastle upon Tyne } \\
\text { Norwich } \\
\text { Nottingham } \\
\text { Oldham } \\
\text { Oxford } \\
\text { Plymouth } \\
\text { Portsmouth } \\
\text { Reading } \\
\text { St. Helens } \\
\text { Salford } \\
\text { Sheffield } \\
\text { Smethwick } \\
\text { Southampton } \\
\text { South Shields } \\
\text { Stockport } \\
\text { Sunderland } \\
\text { Wakefield } \\
\text { Walsall } \\
\text { Warrington } \\
\text { West Bromwich } \\
\text { York } \\
\text { Cardiff } \\
\text { Newport } \\
\text { Swansea } \\
\text { Swant }\end{array}$ & $\begin{array}{r}85 \\
84 \\
124 \\
107 \\
88 \\
101 \\
139 \\
95 \\
109 \\
100 \\
100 \\
84 \\
113 \\
95 \\
129 \\
100 \\
95 \\
87 \\
146 \\
109 \\
89 \\
91 \\
137 \\
124 \\
99 \\
109 \\
150 \\
156 \\
138 \\
145 \\
108 \\
126 \\
91 \\
101 \\
95 \\
116 \\
96 \\
110 \\
157 \\
123 \\
127 \\
116 \\
112 \\
109 \\
117 \\
93 \\
119 \\
130 \\
128 \\
105 \\
113 \\
114 \\
106\end{array}$ & $\begin{array}{r}71 \\
98 \\
106 \\
94 \\
100 \\
84 \\
116 \\
101 \\
90 \\
110 \\
104 \\
70 \\
124 \\
100 \\
102 \\
114 \\
112 \\
100 \\
119 \\
90 \\
75 \\
99 \\
145 \\
104 \\
107 \\
125 \\
122 \\
124 \\
146 \\
119 \\
118 \\
133 \\
78 \\
108 \\
104 \\
120 \\
100 \\
83 \\
128 \\
135 \\
107 \\
126 \\
95 \\
92 \\
130 \\
77 \\
98 \\
131 \\
72 \\
116 \\
117 \\
121 \\
94\end{array}$ & $\begin{array}{r}118 \\
44 \\
86 \\
143 \\
174 \\
196 \\
233 \\
102 \\
203 \\
78 \\
181 \\
213 \\
100 \\
116 \\
124 \\
151 \\
44 \\
54 \\
51 \\
94 \\
191 \\
95 \\
123 \\
188 \\
90 \\
124 \\
235 \\
177 \\
97 \\
119 \\
80 \\
50 \\
209 \\
148 \\
33 \\
50 \\
42 \\
161 \\
277 \\
146 \\
174 \\
73 \\
120 \\
176 \\
126 \\
181 \\
198 \\
226 \\
172 \\
121 \\
61 \\
65 \\
42\end{array}$ \\
\hline
\end{tabular}

